\title{
Ekstraksi Minyak Atsiri Pandan Wangi (Pandanus amaryllifolius Roxb.) dengan Lama Waktu Penyulingan yang Berbeda
}

\section{(Extraction of Pandanus (Pandanus amaryllifolius Roxb.) Essential Oils by Different Durations of Distillation)}

\author{
Maya Damayanti ${ }^{\star}$, Sarifah Nurjanah, Anas Bunyamin, Totok Pujianto
}

(Diterima Januari 2019/Disetujui Agustus 2020)

\begin{abstract}
ABSTRAK
Daun tanaman pandan wangi (Pandanus amaryllifolius Roxb.) dikenal sebagai pemberi aroma pada produk pangan dan sebagai penghasil minyak atsiri. Ekstraksi minyak atsiri dengan metode penyulingan dapat meningkatkan nilai guna dan nilai tambah tanaman tersebut. Tujuan penelitian ini adalah untuk mengetahui lama waktu penyulingan yang menghasilkan rendemen dan mutu minyak pandan wangi terbaik. Metode penelitian yang digunakan ialah metode eksperimen dengan analisis deskriptif. Penelitian ini menggunakan 5 variasi lama penyulingan dan dilakukan pengulangan sebanyak dua kali. Variasi lama waktu penyulingan yang digunakan adalah $2,4,6,8$, dan 10 jam. Parameter yang diamati untuk menentukan perlakuan terbaik terdiri atas jumlah rendemen yang dihasilkan serta parameter mutu yang meliputi berat jenis, indeks bias, bilangan asam, kelarutan dalam alkohol $90 \%$, dan bilangan ester. Berdasarkan hasil penelitian yang dilakukan, lama waktu penyulingan untuk menghasilkan rendemen terbaik adalah perlakuan 8 jam dengan nilai rendemen sebesar $0,55 \%$, sedangkan lama waktu penyulingan untuk menghasilkan mutu terbaik adalah perlakuan 6 jam dengan besar berat jenis $1,0563 \mathrm{~g} / \mathrm{mL}$, indeks bias 1,3473, bilangan asam 3,274 mg KOH/g, kelarutan dalam alkohol $90 \%$ (1:1), dan bilangan ester sebesar $96,06 \mathrm{~mL} \mathrm{HCl} / \mathrm{g}$.
\end{abstract}

Kata kunci: minyak atsiri, pandan wangi, penyulingan air dan uap

\section{ABSTRACT}

The leaves of pandan wangi (Pandanus amaryllifolius Roxb.) are known as food flavor and can be extracted to produce essential oil. Extraction of its essential oil is usually conducted by distillation method that would give added value for this plant. This study aimed to study the effect of different durations of distillation process on the essential oils yield and quality of pandanus using water and steam distillation method. The method used in this research was experimental method with descriptive analysis. This research used five variants duration of distillation, which was repeated two times. The duration of distillation consisted of 2 hours, 4 hours, 6 hours, 8 hours, and 10 hours. The parameters observed to determine the best treatment consisted of the amount of yield produced and the quality parameters including specific gravity, refractive index, acid number, solubility in ethanol $90 \%$, and ester number. Based on the results of the research conducted, distillation to produce the best yield is the duration of 8 hours with a yield value of $0.55 \%$, while distillation to produce the best quality is the duration of 6 hours with a specific gravity of $1.0563 \mathrm{~g} / \mathrm{mL}$, refractive index 1.3473 , the acid number was $3.274 \mathrm{mg} \mathrm{KOH} / \mathrm{g}$, solubility in ethanol $90 \%$ (1:1), and ester number of $96.06 \mathrm{~mL} \mathrm{HCl} / \mathrm{g}$.

Keywords: essential oil, pandan wangi, water and steam distillation

\section{PENDAHULUAN}

Pandan wangi (Pandanus amaryllifolius Roxb.) telah lama dimanfaatkan sebagai pemberi aroma pada makanan. Berdasarkan beberapa penelitian yang telah dilakukan didapatkan bahwa daun pandan wangi mengandung minyak atsiri. Cheetangdee \& Siree (2006) mengemukakan komponen penyusun aroma dasar pada daun pandan wangi berasal dari senyawa kimia 2-acetyl-1-pyrroline. Selain senyawa tersebut,

Program Studi Teknologi Industri Pertanian, Fakultas Teknologi Industri Pertanian, Universitas Padjadjaran, Jl. Raya Bandung Sumedang KM.21, Hegarmanah, Kec. Jatinangor, Sumedang 45363

*Penulis Korespondensi: Email: mayaadmynti@gmail.com
Qurratu'aini (2011) juga menyatakan bahwa terdapat senyawa 3-hexanol yang menyusun komponen aroma pandan wangi dan juga menentukan aroma pandan wangi.

Pengolahan daun pandan wangi menjadi minyak atsiri memiliki peluang yang besar jika dilihat dari nilai ekspor minyak atsiri Indonesia. Nilai ekspor minyak atsiri Indonesia cenderung meningkat setiap tahunnya. Nilai total ekspor minyak atsiri pada tahun 2014 adalah sebesar 156.301 ribu US\$ menjadi 160.368 ribu US\$ pada tahun 2017, dan 199.266 ribu US\$ pada tahun 2018 (www.trademap.org). Nilai ekspor yang meningkat setiap tahunnya menunjukkan bahwa kebutuhan minyak atsiri semakin meningkat sehingga peluang pasar minyak atsiri juga semakin besar. 
Salah satu cara yang dapat digunakan untuk mengekstraksi minyak atsiri adalah dengan penyulingan. Pengusaha skala kecil maupun menengah banyak menggunakan penyulingan air dan uap karena dianggap lebih menguntungkan jika dilihat dari nilai rendemen dan mutu yang dihasilkan karena bahan tidak langsung mengalami kontak dengan air sehingga mengurangi kemungkinan terjadinya oksidasi dan hidrolisis ester (Sulaksana 2015). Salah satu hal yang perlu diperhatikan dalam penyulingan adalah lama waktu penyulingan yang dilakukan karena lama waktu penyulingan yang tidak tepat dapat menurunkan rendemen dan mutu yang dikehendaki (Ginting 2004). Tujuan penelitian ini adalah mengetahui lama waktu penyulingan terbaik untuk menghasilkan rendemen dan mutu minyak pandan wangi terbaik.

\section{METODE PENELITIAN}

Penelitian ini dilakukan pada bulan FebruariAgustus 2018 bertempat di Penyulingan Koperasi Sederhana Sumedang, Laboratorium Pasca Panen dan Teknologi Proses, Laboratorium Keteknikan Pengolahan Pangan, dan Laboratorium Kimia Pangan, Fakultas Teknologi Industri Pertanian, Universitas Padjadjaran. Bahan penelitian yang digunakan adalah daun pandan wangi (Pandanus amaryllifolius Roxb.) yang diambil dari Kecamatan Dampit Kabupaten Subang, $\mathrm{Na}_{2} \mathrm{SO}_{4}$ anidrat, etanol $96 \%$, alkohol $95 \%$,

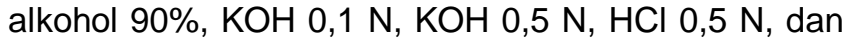
Fenolftalein (pp). Alat yang digunakan pada penelitian ini adalah penyulingan air dan uap. Metode penelitian yang digunakan adalah metode eksperimen laboratorium dengan analisis deskriptif dengan menggunakan 5 perlakuan, yaitu lama penyulingan 2, 4, 6, 8 , dan 10 jam. Masing-masing perlakuan dilakukan 2 kali ulangan.

Pelayuan daun pandan wangi yang dilakukan mengacu pada penelitian Adiyasa et al. (2014), yaitu selama 2 hari di dalam ruangan dan kemudian dirajang dengan ukuran $2 \times 2 \mathrm{~cm}$, sebanyak $1,6 \mathrm{~kg}$. Proses penyulingan dilakukan dengan variasi waktu yang telah ditentukan dengan menggunakan penyulingan air dan uap. Uap-uap air yang dihasilkan ketika proses penyulingan akan mengangkat komponen minyak atsiri yang ada di dalam daun pandan wangi dan kemudian uap-uap tersebut akan terkondensasi sehingga dihasilkan destilat berupa minyak pandan wangi dan air. Destilat yang dihasilkan kemudian dievaporasi dengan suhu $70^{\circ} \mathrm{C}$ untuk memisahkan air dari minyak pandan wangi. Hasil evaporasi ini masih mengandung sedikit air sehingga perlu dilakukan pemisahan menggunakan $\mathrm{Na}_{2} \mathrm{SO}_{4}$ andhidrat dengan perbandingan $\mathrm{Na}_{2} \mathrm{SO}_{4}$ andhidrat dan minyak pandan wangi 1:10. Campuran minyak pandan wangi dan $\mathrm{Na}_{2} \mathrm{SO}_{4}$ andhidrat kemudian disaring sehingga didapatkan minyak pandan wangi (absolute).

Parameter yang dianalisis pada penelitian ini adalah rendemen total dan mutu minyak atsiri yang meliputi berat jenis, indeks bias, bilangan asam, kelarutan dalam alkohol $90 \%$, dan bilangan ester (SNI 06-2385-2006). Selain itu, dilakukan juga perbandingan rendemen dengan konsumsi bahan bakar yang digunakan selama penyulingan untuk mendapatkan nilai efisiensi yang paling tinggi.

\section{HASIL DAN PEMBAHASAN}

\section{Pengaruh Lama Waktu Penyulingan pada Rendemen Minyak Pandan Wangi}

Rendemen total merupakan perbandingan massa absolute dengan massa daun pandan wangi segar hasil sortasi. Dapat dilihat pada Gambar 1 bahwa rendemen total meningkat seiring dengan peningkatan lama waktu penyulingan yang dilakukan.

Hasil penelitian ini sejalan dengan hasil penelitian Qurratu'aini (2011) yang menyatakan bahwa semakin lama waktu penyulingan yang dilakukan maka semakin meningkat rendemen minyak atsiri yang dihasilkan. Hal ini disebabkan karena kontak uap air dengan daun pandan wangi yang semakin lama sehingga komponen minyak atsiri yang terdapat di dalam daun pandan wangi semakin banyak yang terekstraksi. Dengan begitu, rendemen total yang dihasilkan pun semakin meningkat. Dari Gambar 1 dapat dilihat bahwa rendemen tertinggi yang dihasilkan pada perlakuan lama waktu penyulingan $10 \mathrm{jam}$. Akan tetapi, jika dilihat pada Tabel 1, maka perbandingan nilai efisiensi antara massa absolute dengan konsumsi bahan bakar tertinggi didapatkan pada perlakuan dengan lama penyu-

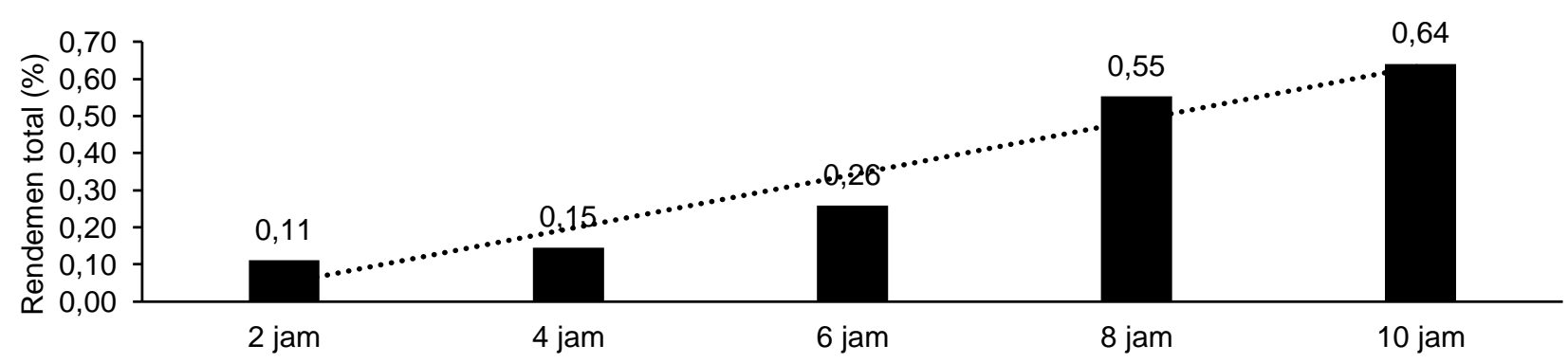

Lama waktu penyulingan

Gambar 1 Pengaruh lama waktu penyulingan pada rendemen total minyak pandan wangi. 
lingan 8 jam, yaitu sebesar 0,37\%. Dengan demikian perlakuan yang dipilih untuk mendapatkan rendemen minyak pandan wangi adalah perlakuan lama waktu penyulingan 8 jam.

\section{Pengaruh Lama Waktu Penyulingan pada Mutu Minyak Pandan Wangi \\ - Berat jenis}

Pengujian berat jenis dilakukan dengan membandingkan antara massa minyak pandan wangi dengan massa air pada suhu dan volume yang sama. Nilai berat jenis yang didapatkan pada penelitian ini berbeda-beda setiap perlakuannya. Nilai berat jenis hasil penelitian ini tertera pada Tabel 2.

Perbedaan nilai berat jenis yang didapatkan dapat dipengaruhi oleh komponen yang terdapat di dalam minyak pandan wangi setiap perlakuan. Menurut Guenther (1987), semakin banyak fraksi bobot komponen dalam minyak atsiri maka berat jenisnya akan semakin besar. Diduga pada perlakuan penyulingan 6 jam mengandung lebih sedikit fraksi bobot komponen sehingga nilai berat jenisnya lebih rendah dibandingkan dengan perlakuan yang lain. Hasil pengamatan dengan GC-MS (Nurjanah et al. 2019) menunjukkan bahwa pada penyulingan selama 2 dan 4 jam, komponen utama yang terbentuk adalah $2(5 \mathrm{H})$ Furanone, 3-methyl dan 4H-Pyran-4-one, 2,3-dihydro3,5-dihydroxy-6-methyl, dan mulai pada penyulingan 6 jam senyawa $2(5 \mathrm{H})$-Furanone, 3-methyl menurun dan senyawa 4H-Pyran-4-one, 2,3-dihydro-3,5-dihydroxy6-methyl tidak terdeteksi. Kedua senyawa ini mempunyai bobot molekul tinggi, terutama $4 \mathrm{H}-\mathrm{Pyran}-$ 4-one, 2,3-dihydro-3,5-dihydroxy-6-methyl $\left(\mathrm{C}_{6} \mathrm{H}_{8} \mathrm{O}_{4}\right)$. Selain itu, pada penyulingan 6 jam menghasilkan komponen citronellic acid sebesar $22,94 \%$ yang mempunyai bobot molekul di bawah senyawa $4 \mathrm{H}-$ Pyran-4one, 2,3-dihydro-3,5-dihydroxy-6-methyl. Pada penyulingan 8 dan 10 jam menghasilkan komponen dengan bobot molekul yang lebih tinggi lagi, seperti geranic acid $\left(\mathrm{C}_{10} \mathrm{H}_{16} \mathrm{O}_{2}\right)$ dan linalool $\left(\mathrm{C}_{10} \mathrm{H}_{18}\right)$.

\section{- Indeks bias}

Sama halnya dengan berat jenis, nilai indeks bias juga berhubungan dengan komponen penyusun minyak pandan wangi. Semakin banyak komponenkomponen dengan rantai panjang maka nilai indeks bias akan semakin tinggi karena cahaya akan semakin sulit dibiaskan. Nilai indeks bias hasil penelitian ini tertera pada Tabel 3.

Semakin banyak senyawa terpena berantai panjang dalam minyak atsiri maka nilai indeks bias pun akan semakin tinggi karena medium semakin rapat sehingga cahaya semakin sukar dibiaskan. Menurut Guzman \& Siemosma (1999), minyak atsiri pandan wangi mengandung 6-42\% hidrokarbon seskuiterpen dan 6\% linalool sebagai monoterpena. Hasil pengamatan dengan GC-MS (Nurjanah et al. 2019) menunjukkan bahwa semakin lama waktu penyulingan semakin meningkat kandungan monoterpen linalool dari $8,13 \%$ menjadi $23,32 \%$.

\section{- Bilangan asam}

Pada penelitian ini didapatkan minyak atsiri yang berbeda-beda pada setiap perlakuan lama waktu penyulingan. Nilai bilangan asam hasil penelitian ini disajikan pada Tabel 4. Nilai bilangan asam mengindikasikan bahwa semakin banyak asam lemak bebas yang terdapat di dalam minyak pandan wangi. Berdasarkan hasil pengamatan dengan GC-MS (Nurjanah et al. 2019) pada perlakuan lama penyulingan 6 jam jumlah komponen asam adalah sebesar $58,1 \%$, sedangkan pada perlakuan lama penyulingan 10 jam adalah sebesar $42,47 \%$. Terdapat perbedaan dari hasil pengujian bilangan asam yang menunjukkan bahwa nilai bilangan asam pada hasil penyulingan selama 6 jam lebih rendah dibandingkan dengan yang diperoleh dari penyulingan 10 jam. Hal ini diduga karena lama penyimpanan pada perlakuan lama penyulingan 10 jam lebih lama dibandingkan dengan perlakuan lama penyu-lingan 6 jam sehingga memungkinkan terjadinya pem-bentukan komponen asam lain selama penyimpanan.

\section{- Kelarutan dalam alkohol $90 \%$}

Pengujian kelarutan dalam alkohol dilakukan untuk mengetahui jumlah alkohol yang dibutuhkan untuk

Tabel 2 Nilai bobot jenis minyak pandan wangi dengan perlakuan 2, 4, 6, 8, dan 10 jam

\begin{tabular}{cc}
\hline Perlakuan (jam) & Bobot jenis $(\mathrm{g} / \mathrm{mL})$ \\
\hline 2 & 1,0812 \\
\hline 4 & 1,0857 \\
6 & 1,0563 \\
8 & 1,0961 \\
10 & 1,1148 \\
\hline
\end{tabular}

Tabel 3 Nilai indeks bias minyak pandan wangi dengan perlakuan 2, 4, 6, 8, dan 10 jam

\begin{tabular}{cc}
\hline Perlakuan (jam) & Indeks bias \\
\hline 2 & 1,3513 \\
4 & 1,3573 \\
6 & 1,3473 \\
8 & 1,3513 \\
10 & 1,3534 \\
\hline
\end{tabular}

Tabel 1 Nilai efisiensi gas dengan perlakuan 2, 4, 6, 8, dan 10 jam

\begin{tabular}{cccc}
\hline Perlakuan (jam) & Massa absolute $(\mathrm{g})$ & Konsumsi bahan bakar $(\mathrm{g})$ & Efisiensi $(\%)$ \\
\hline 2 & 4,00 & 1450 & 0,28 \\
4 & 5,54 & 3000 & 0,18 \\
6 & 8,30 & 4700 & 0,18 \\
8 & 20,34 & 6400 & 0,37 \\
10 & 23,72 & 8000 & 0,30 \\
\hline
\end{tabular}

Keterangan: Warna kuning merupakan perlakuan terbaik. 
melarutkan sejumlah minyak pandan wangi. Nilai kelarutan pada penelitian ini berbeda-beda dan disajikan pada Tabel 5.

Menurut Guenther (1987), semakin banyak kandungan senyawa terpen pada minyak atsiri maka minyak akan semakin sukar larut. Pada penelitian ini, minyak pandan wangi yang paling mudah larut pada alkohol adalah pada perlakuan penyulingan 6 jam. Perlakuan penyulingan 6 jam diduga mengandung senyawa terpena yang lebih rendah dibandingkan dengan perlakuan lainnya sehingga lebih mudah larut dalam alkohol. Nilai kelarutan minyak pandan wangi dalam alkohol yang didapatkan pada penelitian ini bahkan memiliki nilai kelarutan yang lebih baik jika dibandingkan dengan nilai kelarutan pada penelitian Chema (2018), yaitu sebesar 1:2,7.

\section{- Bilangan ester}

Bilangan ester merupakan salah satu parameter yang menandakan bahwa minyak atsiri memiliki aroma yang baik. Bilangan ester pada penelitian ini memiliki nilai yang berbeda-beda pada setiap perlakuan. Nilai bilangan ester hasil penelitian ini disajikan pada Tabel 6.

Jika dilihat pada perlakuan pada Tabel 6, nilai bilangan ester yang dihasilkan pada perlakuan penyulingan 4 jam lebih tinggi dibandingkan dengan perlakuan lama penyulingan lainnya. Akan tetapi, jika dibandingkan dengan nilai bilangan ester minyak kapulaga (Armando 2009) yang berkisar sebesar 90-150 mL $\mathrm{HCl} / \mathrm{g}$ maka nilai bilangan ester minyak pandan wangi masih berada dalam rentang tersebut.

Tabel 4 Nilai bilangan asam minyak pandan wangi dengan perlakuan 2, 4, 6, 8, dan 10 jam

$\begin{array}{cc}\text { Perlakuan (jam) } & \text { Bilangan asam }(\mathrm{mg} \mathrm{KOH} / \mathrm{g}) \\ 2 & 15,41 \\ 4 & 13,20 \\ 6 & 3,27 \\ 8 & 13,12 \\ 10 & 4,85\end{array}$

Tabel 5 Nilai kelarutan dalam alkohol 90\% minyak pandan wangi dengan perlakuan 2, 4, 6, 8, dan 10 jam

\begin{tabular}{cc}
\hline Perlakuan (jam) & Kelarutan dalam alkohol 90\% \\
\hline 2 & $1: 1,09$ \\
4 & $1: 1,20$ \\
6 & $1: 1,00$ \\
8 & $1: 1,03$ \\
10 & $1: 1,30$ \\
\hline
\end{tabular}

Tabel 6 Nilai bilangan ester minyak pandan wangi dengan perlakuan 2, 4, 6, 8, dan 10 jam

\begin{tabular}{cc}
\hline Perlakuan (jam) & Bilangan ester $(\mathrm{mL} \mathrm{HCl} / \mathrm{g})$ \\
\hline 2 & 98,45 \\
4 & 112,09 \\
6 jam & 96,06 \\
8 jam & 98,12 \\
10 jam & 107,21 \\
\hline
\end{tabular}

\section{KESIMPULAN}

Hasil penelitian menunjukkan bahwa lama waktu penyulingan terbaik untuk menghasilkan rendemen minyak pandan wangi terbaik dengan efisiensi tertinggi adalah selama 8 jam dengan nilai rendemen sebesar $0,55 \%$, sedangkan lama waktu penyulingan untuk menghasilkan minyak pandan wangi dengan mutu terbaik adalah selama 6 jam dengan nilai berat jenis sebesar $1,0563 \mathrm{~g} / \mathrm{mL}$, indeks bias sebesar 1,3473, bilangan asam sebesar $3,274 \mathrm{mg} \mathrm{KOH} / \mathrm{g}$, kelarutan dalam alkohol $90 \%$ (1:1), dan bilangan ester sebesar $96,06 \mathrm{~mL} \mathrm{HCl} / \mathrm{g}$.

\section{DAFTAR PUSTAKA}

Adiyasa IWP, Wartini NM, Yoga IWGS. 2014. Karakteristik Minyak Atsiri Daun Pandan Wangi Hasil Perlakuan Lama Curing dan Lama Ekstraksi. Rekayasa dan Manajemen Agroindustri. 2(2): 6776.

Armando R. 2009. Memproduksi 15 Minyak Atsiri Berkualitas. Jakarta (ID): Penebar Swadaya.

Cheetangdee V, Siree C. 2006. Free Amino Acid and Reducing Sugar Composition of Pandan (Pandanus amaryllifolius) Leaves. Kasetsart 40: 67-74.

Chema M. 2018. Komponen Kimia Minyak Atsiri Pandan Wangi (Pandanus amaryllifolius Roxb.) Hasil Destilasi Uap Secara Kromatografi GasSpektrometri Massa. Electronic Theses and Dissetation (ETD). Unsyiah.

Ginting S. 2004. Pengaruh Lama Penyulingan terhadap Rendemen dan Mutu Minyak Atsiri Daun Sereh Wangi. e-USU Repository. 2: 1-22.

Guenther E. 1987. Minyak Atsiri Jilid 1. Jakarta (ID): UIPress.

Guzman CC, Siemosma SS. 1999. Plant Resources of South-East Asia, No.13. Bogor (ID): Spices.

Nurjanah S, Damayanti M, Rahmani AR, Marwah AS, Widyasanti S, Bunyamin A, Putri SH, Nurhadi B. 2019. Komposisi Hasil Ekstraksi Minyak Atsiri Pandan Wangi (Pandanus amaryllifolius Roxb.) dengan Metode Penyulingan dan Microwave. Disampaikan pada Konferensi Nasional Minyak atsiri, Samarinda 16-17 Oktober 2019.

Qurratu'aini E. 2011. Study on Extraction of Pandan Flavor from Pandan Leaves Using Steam Distiliation. [Thesis]. Malaysia: Universiti Malaysia Pahang.

Sulaksana J. 2015. Analisis Nilai Tambah Usaha Penyulingan Minyak Daun Cengkeh (Suatu Kasus di Desa Sukasari Kidul Kecamatan Argapura Kabupaten Majalengka). Agrivert Journal. 3: 1-28. 